AperTO - Archivio Istituzionale Open Access dell'Università di Torino

\title{
H3 receptor renal expression in normal and diabetic rats
}

\section{This is the author's manuscript}

Original Citation:

Availability:

This version is available http://hdl.handle.net/2318/158681

since 2016-11-11T15:28:57Z

Published version:

DOI:10.1007/s00011-015-0808-y

Terms of use:

Open Access

Anyone can freely access the full text of works made available as "Open Access". Works made available under a Creative Commons license can be used according to the terms and conditions of said license. Use of all other works requires consent of the right holder (author or publisher) if not exempted from copyright protection by the applicable law. 


\section{(2) \\ UNIVERSITÀ DEGLI STUDI DI TORINO}

The final publication is available at Springer via

http://www.springerlink.com/openurl.asp? genre=article \&id=doi:10.1007/ s00011-015-0808-y 


\section{$\mathrm{H}_{3}$ receptor renal expression in normal and diabetic rats.}

Alessandro Pini ${ }^{*}$, Paul L Chazot $^{2 *}$, Eleonora Veglia ${ }^{3}$, Aldo Moggio ${ }^{3}$, Arianna Carolina Rosa $^{3}$

*Authors contributed equally to this work

${ }^{I}$ Dipartimento di Medicina Sperimentale e Clinica Sezione di Anatomia e Istologia Università degli Studi di Firenze,

Largo Brambilla 3, 50134 Florence, Italy; ${ }^{2}$ School of Biological and Biomedical Sciences and Wolfson Research Institute, Durham University, South Road, Durham DH1 3LE, UK; ${ }^{3}$ Dipartimento di Scienza e Tecnologia del Farmaco, Università di Torino, Via P. giuria 9, 10125 Turin, Italy;

Corresponding authors Arianna Carolina Rosa, $\mathrm{PhD}$

Dipartimento di Scienza e Tecnologia del Farmaco, University of Turin, Italy, Via P. Giuria 9, 10125, Turin, Italy

Phone: +390116707955

Fax: +390116707688

e-mail: ariannacarolina.rosa@unito.it 


\begin{abstract}
Introduction

In order to extend our previous observation of $\mathrm{H}_{4} \mathrm{R}$ upregulation in the kidney of diabetic rats, we evaluated in the same specimens the presence of the $\mathrm{H}_{3} \mathrm{R}$.

Materials and methods

Kidney specimens from 24 8-week-old male Wistar rats (12 non-diabetic and 12 diabetic animals) were processed for both immunohistochemical and immunofluorescence analyses.

Results and conclusion

$\mathrm{H}_{3} \mathrm{R}$ is expressed in the apical membrane by collecting duct cells in the kidney of rats and it is significantly increased in diabetic animals. These data support the hypothesis that $\mathrm{H}_{3} \mathrm{R}$ could also mediate non-neuronal histamine effects, suggesting its involvement in fluid homeostasis.
\end{abstract}

Key Words histamine $\mathrm{H}_{3}$ receptor, histamine, kidney, diabetes, collecting ducts 


\section{Introduction}

Recently, our group demonstrated the presence of the histamine $\mathrm{H}_{4}$ receptor $\left(\mathrm{H}_{4} \mathrm{R}\right)$ in resident renal cells of the loop of Henlé and its profound upregulation in the kidney of diabetic rats[1]. This observation adds to independent evidence of a role for histamine in renal (patho)physiology. In healthy subjects the administration of loading doses of L-histidine led to an increase of histamine concentration in urine. In renal transplant patients the urinary and blood levels of histamine are elevated. In the kidney of diabetic rats, histamine was increased compared with controls[2]. Basically, histamine has been reported to regulate the renal microcirculation, to increase salt and water excretion[3-5], decrease the ultrafiltration coefficient by reducing the total filtration surface area[4], and increase renin release[6].

The aim of this study was to extend our previous observation on $\mathrm{H}_{4} \mathrm{R}$ in healthy and diabetic rats evaluating in the same specimens the renal expression of $\mathrm{H}_{3} \mathrm{R}$.

\section{Materials and Methods}

Animals, protocols, diabetes induction, biochemical and histological parameters have been previously reported[1]. Conventional immunohistochemical procedures were employed as described. Immunoperoxidase staining for $\mathrm{H}_{3} \mathrm{R}$ was performed on $5 \mu \mathrm{m}$ kidney sections for formalin-fixed tissue from 24 male 8-week-old Wistar rats (12 non-diabetic and 12 diabetic animals). Renal sections were incubated overnight with anti- $\mathrm{H}_{3} \mathrm{R}(349-358)(2 \mu \mathrm{g} / \mathrm{ml})[7]$, followed by a three-layer streptavidin-biotin-peroxidase complex staining method. Photomicrographs were acquired randomly with a digital camera connected to a light microscope equipped with a $\mathrm{x} 40$ objective (Leica DM750). Images were processed by ImageJ 1.41 (NIH, USA) software and quantified using the Color Deconvolution image analysis tool. The percentage area was calculated for $\mathrm{H}_{3} \mathrm{R}$-positive tissue. Values are mean \pm SEM of the optical density (in arbitrary units) measurements of individual rats (ten images/zone each) from the different experimental groups. For immunofluorescence and confocal analysis, after antigen retrieval and blocking, kidney sections were incubated with primary anti- $\mathrm{H}_{3} \mathrm{R}$ and anti-AQP2, antibody, followed by incubation with corresponding Alexa Fluor secondary antibodies. After counterstaining with DAPI, photomicrographs were obtained by Apotome systems (Zeiss) at x40 objective. The percentage of positive cells for $\mathrm{H}_{3} \mathrm{R}$ and AQP2 was determine by ImageJ 1.41 software. Values are expressed as mean \pm SEM positive cell/collecting duct percentage of individual rats (ten images/zone each) from the different experimental groups.

To confirm the absence of false staining, tissue was also screened in the absence of primary antibodies and following pre-incubation with (349-358) peptide (data not shown). All sections were immunostained in a single session to minimize artifactual differences. 


\section{Results}

The immunohistochemical analysis (Fig. 1A) revealed a clear $\mathrm{H}_{3} \mathrm{R}$-like immunoreactivity in control rats, predominantly in the renal medulla and the papilla. In contrast, in the cortex the immunoreactivity was generally very low, and no signal was detected in the glomeruli. Notably, when diabetic and non-diabetic animals were compared, a significant increase in immunoreactivity, suggestive of $\mathrm{H}_{3} \mathrm{R}$ receptor upregulation, was observed (Fig 1B).

The above data, indicating a higher $\mathrm{H}_{3} \mathrm{R}$-like immunoreactivity in the apical membrane of epithelial tubular cells mosty located in medulla and papilla, suggested a collecting duct expression profile for the receptor. To confirm this result, immunoflorescence co-staining was performed with AQP2, expressed in the apical membrane by collecting duct cells in the kidney. As shown in Fig. $1 \mathrm{C}$ and Fig. 1D, most of the $\mathrm{H}_{3} \mathrm{R}$ positive cells were also positive with AQP2, consistent with a predominant $\mathrm{H}_{3} \mathrm{R}$ expression at the apical membrane of the epithelial cells of the collecting ducts.

\section{Discussion}

We demonstrate for the first time that the $\mathrm{H}_{3} \mathrm{R}$ is mainly expressed in the apical membrane by collecting duct cells of the rat, and that this protein is significantly upregulated in the kidneys of diabetic animals. Our histochemical data add the collecting duct cells to the growing list of non-neuronal $\mathrm{H}_{3} \mathrm{R}$-expressing cells already reported[7-9], thus providing further evidence for a role of $\mathrm{H}_{3} \mathrm{R}$ in mediating non-neuronal histamine effects. The collecting duct plays a pivotal role in kidney function and homeostasis by regulating ions and water transport. AQP2 abundance in the apical membrane is strictly involved in the mechanisms for regulation of water reabsorption and urine concentration[10]. The ability to concentrate urine is impaired in conditions such as diabetes insipidus, Histamine, whose levels have been reported to be increased in the kidney of diabetic animals[2], has been shown to increase salt and water excretion[8-10]. Consistent with the observation that histamine induces AQP4 internalization in human AQP4-expressing gastric cells[11], we could speculate that $\mathrm{H}_{3} \mathrm{R}$ may subserve an AQP2 trafficking role in renal duct cells. Indeed, It is known that Gi-coupled GPCRs, of which $\mathrm{H}_{3} \mathrm{R}$ is a member, are required for cAMP-triggered trafficking of AQP2[12]. Herein, we observed that all the diabetic animals, which have shown renal damage[1], expressed profoundly higher levels of $H_{3} R$, thus suggesting a strong association. Notably, data obtained on human tubular cells suggested a similar $\mathrm{H}_{3} \mathrm{R}$ intranephron expression. Therefore, we could speculate that our data on diabetic rats could have a positive translation to diabetic patients. However, whether this receptor has a compensatory or pathological implication and its role as a pharmacological target in diabetic nephropathy remains to be established.

\section{Acknowledgments}


This work was supported by the Royal College of Anaesthesia/BJA, COST Action BM0806 (STSM hosted by the University of Durham) and the Ateneo/CSP2012 (H4 Histamine Receptor As A New Pharmacological Target For The Treatment Of Diabetic Nephropathy - HISDIAN) and Università degli Studi di Torino. 


\section{Reference}

1. Rosa AC, Grange C, Pini A, Katebe MA, Benetti E, Collino M, et al. Overexpression of histamine H(4) receptors in the kidney of diabetic rat. Inflamm Res 2013; 62:357-65.

2. Markle RA, Hollis TM, Cosgarea AJ. Renal histamine increases in the streptozotocin-diabetic rat. Exp Mol Pathol 1986; 44:21-8.

3. Banks RO, Fondacaro JD, Schwaiger MM, Jacobson ED. Renal histamine $\mathrm{H}_{1}$ and $\mathrm{H}_{2}$ receptors: characterization and functional significance. Am J Physiol 1978; 235:F570-5.

4. Ichikawa I, Brenner BM. Mechanisms of action of hisamine and histamine antagonists on the glomerular microcirculation in the rat. Circ Res 1979; 45:737-45.

5. Sinclair RJ, Bell RD, Keyl MJ. Effects of prostaglandin E2 (PGE2) and histamine on renal fluid dynamics. Am J Physiol 1974; 227:1062-6.

6. Schwertschlag U, Hackenthal E. Histamine stimulates renin release from the isolated perfused rat kidney. Naunyn Schmiedebergs Arch Pharmacol 1982; 319:239-42.

7. Morini G, Becchi G, Shenton FC, Chazot PL, Grandi D. Histamine $\mathrm{H}_{3}$ and $\mathrm{H}_{4}$ receptors are expressed on distinct endocrine cell types in the rat fundic mucosa. Inflamm Res 2008; 57 Suppl 1:S57-8.

8. Abboud HE, Ou SL, Velosa JA, Shah SV, Dousa TP. Dynamics of renal histamine in normal rat kidney and in nephrosis induced by aminonucleoside of puromycin. J Clin Invest 1982; 69:327-36.

9. Francis H, Franchitto A, Ueno Y, Glaser S, DeMorrow S, Venter J, et al. H3 histamine receptor agonist inhibits biliary growth of BDL rats by downregulation of the cAMP-dependent PKA/ERK1/2/ELK-1 pathway. Lab Invest 2007; 87:473-87.

10. Pearce D, Soundararajan R, Trimpert C, Kashlan OB, Deen PM, Kohan DE. Collecting duct principal cell transport processes and their regulation. Clinical journal of the American Society of Nephrology : CJASN $2015 ; 10: 135-46$.

11. Carmosino M, Procino G, Nicchia GP, Mannucci R, Verbavatz JM, Gobin R, et al. Histamine treatment induces rearrangements of orthogonal arrays of particles (OAPs) in human AQP4-expressing gastric cells. The Journal of cell biology 2001; 154:1235-43.

12. Valenti G, Procino G, Liebenhoff U, Frigeri A, Benedetti PA, Ahnert-Hilger G, et al. A heterotrimeric G protein of the Gi family is required for cAMP-triggered trafficking of aquaporin 2 in kidney epithelial cells. $\mathrm{J}$ Biol Chem 1998; 273:22627-34. 
Fig. $1 H_{3} R$ renal expression. Representative micrographs of transverse kidney sections, immunolabelled with specific anti- $\mathrm{H}_{3} \mathrm{R}$ antibody (A). Quantitative assessment of $\mathrm{H}_{3} \mathrm{R}$ expression in the kidney; results are the mean $\pm \mathrm{SEM}$ of the optical density (arbitrary units) of individual rats (ten images/ zone) performed in duplicate. Data were analyzed by oneway analysis of variance (ANOVA) and the Student-Newman-Keuls test. $* * P<0.01$ and $* * * P<0.001$ vs. control (B). Immunofluorescence double-staining showing both $\mathrm{H}_{3} \mathrm{R}$ (green) and AQP2 (red)-positive cells (C). Quantitative $\mathrm{H}_{3} \mathrm{R}$ and AQP2-positive cells; results are the mean \pm SEM of positive cell/collecting ducts percentage of individual rats (ten images/zone) performed in duplicate (D).
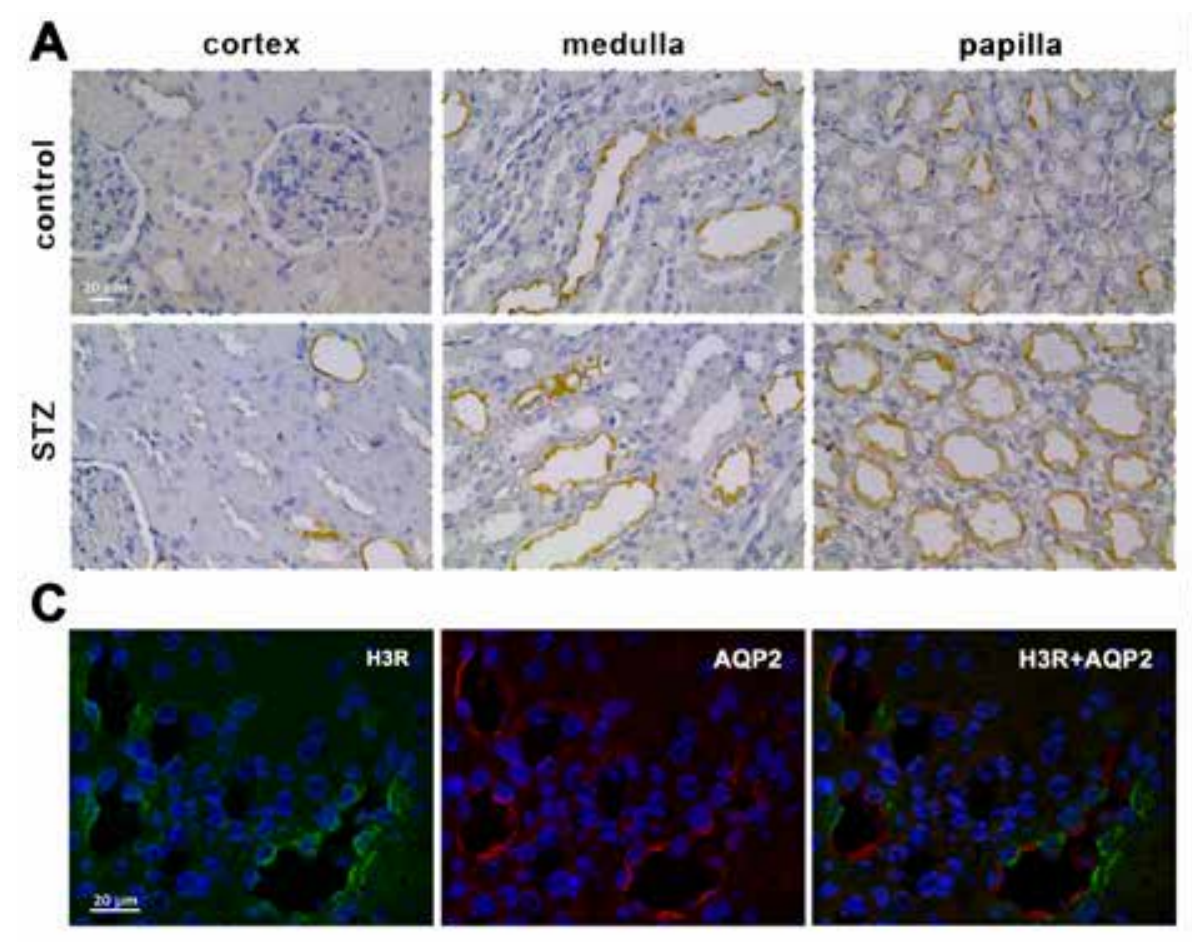

B
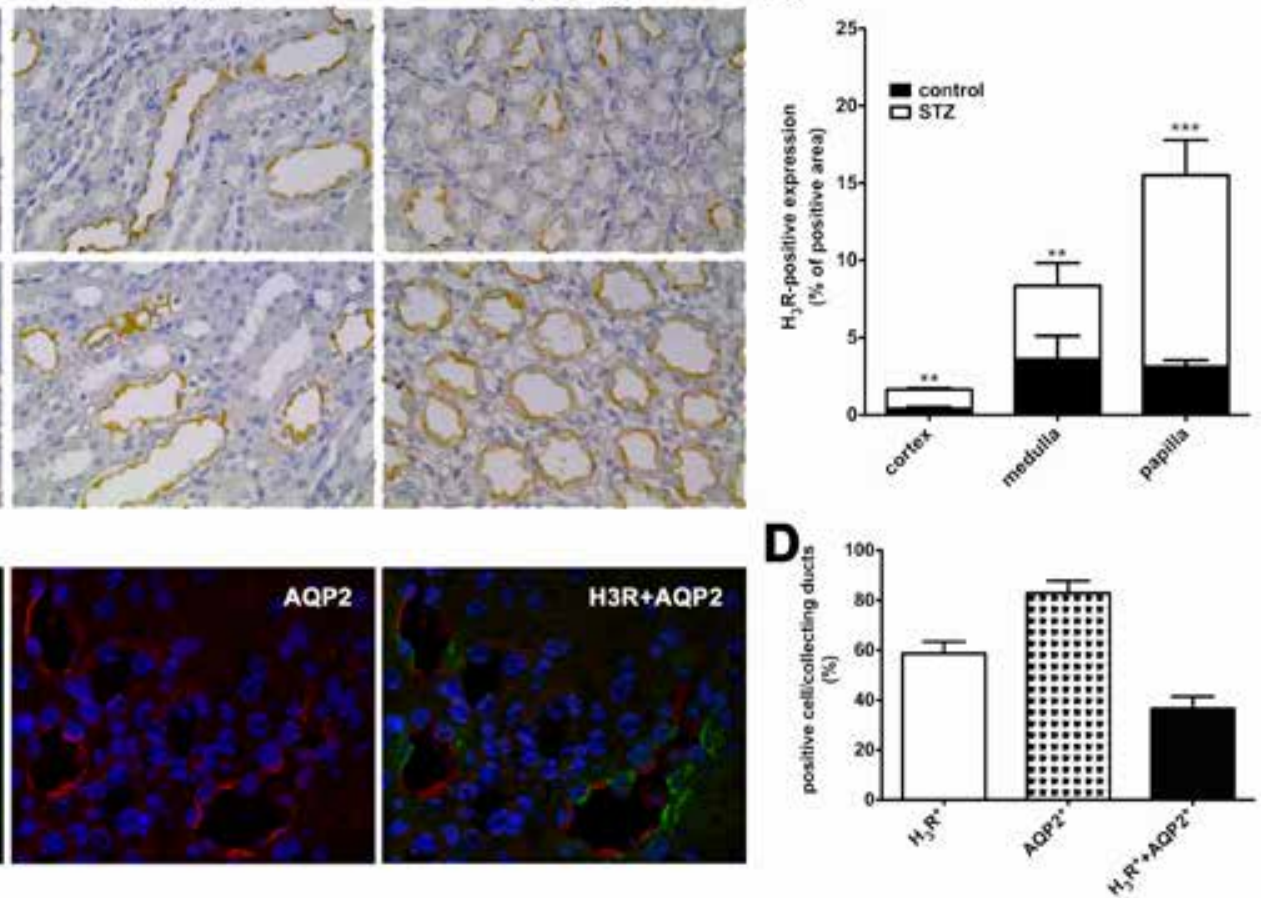